\title{
PENGEMBANGAN HANDOUT KURIKULUM 2013 BERBASIS KOMPETENSI PESERTA DIDIK ABAD 21 KELAS IV DI SD NEGERI KEMBARAN
}

\author{
Dhini Aprilia Utami ${ }^{1}$, Sony Irianto $^{2}$, Sri Muryaningsih ${ }^{3}$ \\ Program Studi Pendidikan Guru Sekolah Dasar, Fakultas Keguruan dan Ilmu Pendidikan \\ Universitas Muhammadiyah Purwokerto \\ e-mail: 1dhini895@gmail.com, ${ }^{2}$ sony_irianto@yahoo.com, ${ }^{3}$ srimuryaningsihump@gmail.com
}

\begin{abstract}
Abstrak
Bahan ajar yang sering digunakan peserta didik di sekolah adalah Lembar Kerja Peserta Didik (LKPD) karena harganya yang ekonomis dan relatif terjangkau. Banyak sekolah yang hanya menggunakan Lembar Kerja Peserta Didik (LKPD) saja tanpa adanya handout atau buku penunjang sebagai pegangan peserta didik sehingga yang digunakan anak untuk belajar secara mandiri masih kurang atau terbatas. Penelitian ini bertujuan untuk mengembangkan handout berbasis kompetensi peserta didik abad 21 menggunakan model pembelajaran TPS (Think-Pair-Squre), mengetahui kelayakan handout, mengetahui respon guru dan peserta didik. Metode yang digunakan peneliti adalah pengembangan (research and development). Proses penelitian pengembangan handout ini menggunakan model pengembangan 4D yang terdiri dari: (1) tahap pendefinisian, (2) tahap perancangan, (3) tahap pengembangan dan (4) tahap penyebaran. Instrumen dan pengumpulan data yang digunakan yaitu wawancara guru, lembar angket penilaian validasi, lembar angket respon guru dan lembar angket peserta didik. Uji coba yang dilakukan pada penelitian ini adalah ujicoba produk pada kelas IV SD Negeri Kembara. Hasil penelitian menyatakan bahwa perolehan respon guru terhadap penilaian bahan ajar handout mendapatkan nilai rata-rata yaitu 4,75 dengan kriteria "sangat baik", sehingga dapat disimpulkan bahan ajar handout tersebut layak digunakan. Hasil penilaian respon peserta didik terhadap bahan ajar handout diperoleh rata-rata 4,51 maka dikategorikan "sangat baik". Jadi, dapat disimpulkan bahwa bahan ajar handout dapat diterima oleh peserta didik sebagai bahan ajar yang mampu membantu proses pembelajaran.
\end{abstract}

Kata Kunci: Bahan Ajar, Handout, Kompetensi, Model Pembelajaran TPS

\begin{abstract}
Teaching materials are often used by students in schools are student worksheets (LKPD) because the price is economize and relatively affordable. many schools only use lkpd without handouts or supporting books as a guide for students so that what children use for learning is still limited. This study aims to develop competency-based handouts of 21 st century students using think pair share (tps) learning knowing the feasibility of handouts, knowing the responses of teachers and students. the method used by researchers is research and development. The handout development research process uses a 4D development model consisting of the stages of defining, designing, developing, and distributing. instruments and data collection used were teacher interviews, validation assessment questionnaire sheets, teacher response questionnaire sheets and student questionnaire sheets. The trials conducted in this study were trials of grade IV to wander country products. the results of the study stated that the acquisition of teacher responses to the study of handout teaching materials received an average value of 4.75 with very good criteria so it can be concluded that the handout teaching materials were suitable for use. the results
\end{abstract}


of the assessment of students' responses to the handout teaching materials obtained an average of 4.51 then very well categorized. so it can be concluded that the handout teaching materials can be accepted by students as teaching materials that can help the learning process.

Keywords: teaching materials, handouts, competencies, tps learning model

Al Qalam: Jurnal Ilmiah Keagamaan dan Kemasyarakatan

Vol. 14, No. 2, Januari-Juni 2020 


\section{PENDAHULUAN}

Memasuki abad 21, pendidikan menjadi semakin penting untuk menjamin peserta didik agar mempunyai keterampilan (life skills). ${ }^{1}$ Keterampilan sesuai abad 21 dimana peserta didik harus memiliki kompetensi berpikir dan belajar. Kompetensi-kompetensi tersebut diantaranya 4C yaitu critical thinking and problem solving, communication, collaboration and creativity or innovation. Tuntutan abad 21 tidak hanya pada peserta didik namun juga menekankan guru harus memiliki kreatifitas. Guru memegang peranan penting untuk membentuk watak dan karakter peserta didik. Kreatifitas yang harus dimiliki guru salah satunya adalah menyusun dan mengembangkan bahan ajar yang akan digunakan agar proses pembelajaran lebih menarik. Bahan ajar merupakan seperangkat materi yang disusun secara sistematis, baik tertulis maupun tidak, sehingga tercipta lingkungan atau suasana yang memungkinkan peserta didik untuk belajar. ${ }^{2}$ Bahan ajar sendiri memiliki karakteristik yang bersifat mandiri, menjelaskan tujuan instruksional yang akan dicapai, memotivasi dan mengantisipasi kesulitan peserta didik dengan menyediakan bimbingan belajar, memberi latihan yang cukup, menyediakan rangkuman, dan berorientasi kepada peserta didik secara individual. ${ }^{3}$

Menarik atau tidaknya proses pembelajaran dipengaruhi oleh faktor bentuk bahan ajar yang digunakan. Bentuk bahan ajar bermacam-macam salah satunya adalah bentuk bahan ajar cetak. Penggunaan bahan ajar selama pembelajaran juga menciptakan suasana belajar yang lebih atraktif dan komunikatif serta mengurangi dominasi guru selama pembelajaran berlangsung. Bahan ajar disesuaikan dengan tuntutan kurikulum yang berlaku.

Tahun pelajaran 2013/2014, pemerintah telah memberlakukan kurikulum baru yaitu kurikulum 2013 sebagai pembaharuan Kurikulum Tingkat Satuan Pendidikan (KTSP). Kurikulum 2013 merupakan sebuah kurikulum yang mengutamakan pemahaman, skill, dan pendidikan berkarakter, peserta didik dituntut untuk memahami materi, aktif dalam berdiskusi dan presentasi serta memiliki sopan santun disiplin yang

${ }^{1}$ Wijaya, E. Y., Sudjimat, D. A., \& Nyoto, A. (2016). Transformasi Pendidikan Abad 21 Sebagai Tuntutan Pengembangan Sumber Daya Manusia Di Era Global. Jurnal Pendidikan, 1, 263-278

${ }^{2}$ Prastowo, A. 2014. Pengembangan Bahan Ajar Tematik. Jakarta: Kencana Prenada Media Group.

${ }^{3}$ Octaviani, S. 2017. Pengembangan Bahan Ajar Tematik Dalam Implementasi Kurikulum 2013 Kelas 1 Sekolah Dasar. EduHumaniora Jurnal Pendidikan Dasar Kampus Cibiru. 9 (2): 93-98.

Al Qalam: Jurnal Ilmiah Keagamaan dan Kemasyarakatan

Vol. 14, No. 2, Januari-Juni 2020 
tinggi. ${ }^{4}$ Tujuan dari Kurikulum 2013 adalah mempersiapkan insan Indonesia untuk memiliki kemampuan hidup sebagai pribadi dan warga negara yang produktif, kreatif, inovatif, dan efektif serta mampu berkontribusi pada kehidupan bermasyarakat, berbangsa, bernegara dan peradaban dunia. ${ }^{5}$ Kurikulum 2013 menggunakan pembelajaran tematik terpadu yaitu pendekatan pembelajaran yang mengintegrasikan beberapa kompetensi dan mata pelajaran ke dalam berbagai tema. Keunggulan dari pembelajaran tematik terpadu pada kurikulum 2013 yaitu dapat memberikan pengalaman, kegiatan belajar yang relevan dengan tingkat dan perkembangan peserta didik.

Pada era global saat ini, peserta didik dituntut mempunyai kreativitas (creativity), kemampuan berpikir kritis (critical thinking), berkomunikasi (communication), dan berkolaborasi (collaboration), yang lebih dikenal dengan akronim 'Four C'. ${ }^{6}$ Kompetensi pada abad 21 diharapkan peserta didik memiliki kemampuan berpikir kritis yang artinya kemampuan seseorang untuk menilai sesuatu secara orisinal sedangkan menurut Boonjeam, dkk menjelaskan bahwa setiap tingkatan proses belajar harus menekankan pada pelatihan peserta didik untuk critical thinking. ${ }^{7}$ Kemampuan komunikasi adalah kemampuan peserta didik menyampaikan ide baik secara lisan maupun secara tulisan. ${ }^{8}$ Collaborative (kolaborasi) adalah kemampuan berkolaborasi atau bekerja sama, saling bersinergi, beradaptasi dalam berbagai peran dan tanggungjawab, bekerja secara produktif dengan yang lain, menempatkan empati pada tempatnya, menghormati. Kemampuan berpikir kreatif yaitu kemampuan untuk menumbuhkan suatu ide-ide atau gagasan baru. Kreatif berhubungan dengan menemukan dan menghasilkan. ${ }^{9}$

\footnotetext{
${ }^{4}$ Kurniaman, O., \& Noviana, E. 2017. Penerapan Kurikulum 2013 Dalam Meningkatkan Keterampilan, Sikap, Dan Pengetahuan. Primary: Jurnal Pendidikan Guru Sekolah Dasar. 6 (2): 389-396.

${ }^{5}$ Kemendikbud. 2013. Peraturan Menteri Pendidikan dan Kebudayaan No 67 Tahun 2013, tentang Kerangka Dasar dan Struktur Kurikulum SD/MI. Jakarta: Kementerian Pendidikan dan Kebudayaan Direktorat Jenderal Pendidikan Dasar.

${ }^{6}$ Anriani, N., \& Fathurrohman, M. 2018. Pengembangan bahan ajar matematika berbasis kompetensi abad 21 untuk guru smp / mts. Prosiding Seminar dan Diskusi Nasional Pendidikan Dasar 2018. 1-5, diakses 05 November 2019.

${ }^{7}$ Boonjeam, dkk. 2017. Program development for primary school teachers 'critical thinking'. International Education Studies. 10 (02).https://files.eric.ed.gov/fulltext/EJ1130350.pdf, diakses pada 22 Januari 2020.

${ }^{8}$ Hodiyanto. 2017. Kemampuan komunikasi matematis dalam pembelajaran matematika. Admathedu. 7 (01): 9-18.

${ }^{9}$ Susanti, D., \& Risnanosanti. 2019. Pengembangan Buku Ajar untuk Menumbuh kembangkan Kemampuan 4C (Critical, Creative, Collaborative, Communicative) melalui Model PBL pada Pembelajaran Biologi di SMP 5 Seluma. Prosiding Seminar Nasional Sains Dan Enterpreneurship VI. 1-9, diakses 11 Januari 2020.
} 
Peneliti melakukan penelitian di SD Negeri Kembaran. SD Negeri Kembaran merupakan sekolah dasar yang sudah menerapkan kurikulum 2013 sejak 2-3 tahun lalu dari kelas 1, 2, 3, 4, 5 dan 6. Sekolah ini sudah menerapkan kurikulum 2013 karena sebagai sekolah inti dari penerapan kurikulum 2013. Fakta di sekolah menunjukkan bahwa untuk ketersediaan bahan ajar masih sederhana belum ada inovasi yang menarik, buku guru dan buku peserta didik sebagai pedoman acuan guru, bahan ajar cetak berupa print out yang digunakan hanya materi-materi belum mengacu pada kompetensi peserta didik abad 21.

Kekurangan yang dimaksudkan adalah kurang jelasnya penggunaan isi materi mengenai bab yang sedang di ajarkan dan kurang menariknya tampilan dari handout tersebut yang cenderung hanya berupa teks, tidak ada ilustrasi berupa gambar atau hal lain yang berisi informasi mengenai pelajaran yang bisa membuat peserta didik tertarik untuk membaca dan mempelajarinya. Terlebih lagi dengan model pembelajaran yang diterapkan oleh guru pada umumnya masih konvensional, disini peran dan semangat peserta didik akan sedikit banyak berkurang dengan model pembelajaran yang seperti itu. Tentunya ini akan berdampak pada kurangnya pemahaman suatu materi pembelajaran dan tidak membuat pelaksanaan kegiatan pembelajaran berjalan secara efektif oleh peserta didik dikarenakan materi pembelajaran yang kurang jelas dari isi materi handout tersebut. $^{10}$

Handout merupakan bahan ajar yang dituangkan secara ringkas sebagai pegangan dalam proses pembelajaran, dapat membantu peserta didik dalam mengikuti pembelajaran secara lebih terarah dan terfokus karena handout adalah kisi-kisi materi ajar yang akan disampaikan oleh guru. ${ }^{11}$ Pengembangan bahan ajar berupa handout kurikulum 2013 yang berbasis kompetensi peserta didik abad 21 bertujuan untuk membantu kecakapan guru atau peserta didik setelah menggunakan bahan ajar pada tema 7 disusun dengan menggunakan ringkasan singkat dan jelas serta gambar atau ilustrasi. Tidak hanya dari bahan ajarnya saja yang perlu dikembangkan namun juga untuk mewujudkan proses pembelajaran agar menarik perlu adanya model pembelajaran. Model pembelajaran yang terkait dengan kompetensi abad 21 yaitu model kolaboratif tipe TPS (Think-Pair-Squre).

${ }^{10}$ Susanto, W. N., \& Nurtjahyani, S. D. (2018). Pengembangan Handout Biologi Berbasis Discovery Learning pada Materi Interaksi Mahluk Hidup dengan Lingkungannya Development of Discovery Learning Based Biology Handout on Creative Interaction Materials With its Environment. Proceeding Biology Education Conference, 15, 471-477. Press.

${ }^{11}$ Prastowo, A. 2015. Panduan Kreatif Membuat Bahan Ajar Inovatif. Jogjakarta: DIVA 
Model pembelajaran TPS memberikan peserta didik kesempatan untuk bekerja sendiri dan bekerjasama dengan peserta didik lain. Model pembelajaran ini peserta didik dituntut untuk aktif dan tidak boleh menjadi pasif karena peserta didik adalah pusat dalam proses belajar mengajar. Tujuan model pembelajaran TPS (Think-Pair-Squre) adalah untuk menyelesaikan masalah dengan cara berkelompok, untuk membiasakan peserta didik berlatih mendengarkan ide-ide atau gagasan peserta didik lain. ${ }^{12}$

Berdasarkan latar belakang diatas, peneliti tergugah untuk mengembangkan bahan ajar handout kurikulum 2013 berbasis kompetensi peserta didik abad 21 Tujuan penelitan ini guna untuk mengembangkan bahan ajar handout berbasis kompetensi peserta didik abad 21, mengetahui kelayakan bahan ajar handout, mengetahui respon guru dan peserta didik.

\section{METODE}

Pengembangan ini menggunakan metode penelitian dan pengembangan (Research and Development). Research and Development merupakan suatu proses atau langkahlangkah untuk mengembangkan suatu produk baru atau menyempurnakan produk yang sudah ada dan dapat dipertanggungjawabkan. Model pengembangan perangkat pembelajaran model 4D yang disarankan oleh S. Thiagharajan, Dorothy S, Semmel, dan Melvyn I. Semmel (1974) dalam Trianto (2013: 189) terdiri dari 4 tahap yaitu Pendefinisian (Define), Perancangan (Design), Pengembangan (Develop) dan Penyebarluasan (Disseminate). ${ }^{13}$ Desain uji coba yang dilakukan menggunakan uji coba secara terbatas. Uji coba ini bertujuan untuk mengetahui respon guru dan peserta didik dari hasil pengembangan bahan ajar handout dalam pembelajaran di kelas. Subjek uji coba pengembangan bahan ajar ini dilakukan di SD Negeri Kembaran kelas IV. Instrumen dan teknik analisis data yang digunakan dalam penelitian ini berupa lembar angket validasi, lembar angket respon guru dan lembar angket pesert didik.

\section{HASIL DAN PEMBAHASAN}

Salah satu tujuan penelitian ini adalah untuk menghasilkan bahan ajar handout kurikulum 2013 berbasis kompetensi peserta didik abad 21 yang layak dan praktis di SD Negeri Kembaran kemudian dikembangkan pada skala yang terbatas dengan kelompok

\footnotetext{
${ }^{12}$ Yaqin, M., A, dkk. 2018. Think-pair-square learning: improving student's collaborative skills and cognitive learning outcome on animal diversity course. Jurnal Pendidikan Biologi Indonesia (Indonesian Journal of Biology Education). 4 (2):135-142.

${ }^{13}$ Trianto. 2013. Mendesain Model Pembelajaran Inovatif-Progresif. Jakarta: Kencana Prenada Media Group.
} 
lebih kecil. Untuk memenuhi tujuan tersebut, dilakukan penelitian pengembangan dengan menggunakan model 4-D. Adapun kegiatan dan hasil yang diperoleh dari tiap tahapannya sebagai berikut:

\section{Tahap Define (Pendefinisian)}

Tahap pendefinisian dilakukan diawali dengan menganalisis fenomena apa saja yang dihadapi pada saat proses pembelajaran khususnya kelas IV SD Negeri Kembaran. Peserta didik kelas IV mempunyai karakteristik yang berbeda-beda seperti menyukai gambar-gambar atau ilustrasi yang menarik berkaitan dengan kehidupan sehari-hari. Ada juga peserta didik yang aktif dan pasif dalam mengikuti pembelajaran, malu untuk menyampaikan argumennya, kerjasama antar teman kurang namun memiliki kreatifitas yang tinggi. Karakteristik peserta didik yang berbeda perlu adanya pengembangan bahan ajar yang kreatif dan inovatif. Hal ini sesuai dengan penelitian yang dilakukan oleh Fajri (2018) yaitu bahwa bahan ajar yang baik dan benar adalah bahan ajar yang sesuai kurikulum dan sesuai dengan karakteristik peserta didik. ${ }^{14}$ Analisis tugas bertujuan untuk mengidentifikasi tugas-tugas utama yang akan dilakukan oleh peserta didik terkait materi pada tema 7 sub tema 1 pembelajaran 2 contohnya pemberian tugas tentang materi tanda tempo dan tinggi rendah nada, tugas tentang pemanfataan gaya oto dalam kehiduopn sehari-hari dan menggali informasi.

2. Tahap Design (Desain)

Tahap desain diawali dengan penyusunan tes acuan patokan untuk mengetahui kemampuan peserta didik terhadap perubahan afektif, psikomotor dan koginitif. Pemilihan bahan ajar yang digunakan berupa handout bertujuan untuk mengetahui perkembangan kompetensi peserta didik khususnya abad 21. Hal ini berguna untuk membantu peserta didik dalam pencapaian kompetensi inti dan kompetensi dasar yang diharapkan. Pemilihan format bahan ajar handout yang dikembangkan berupa cover, hak cipta, prakata, tentang bahan ajar, kompetensi ini, kompetensi dasar dan pengembangan indikator, tujuan pembelajaran, daftar isi, kegiatan pembelajaran, daftar pustaka, dan biodata penulis. Rancangan awal disusun sebelum di serahkan pada dosen pembimbing mengenai produk yang akan dikembang agar mengetahui layak atau tidaknya produk yang akan di ujicobakan.

3. Tahap Develop (Pengembangan)

${ }^{14}$ Fajri, Z. 2018. Bahan Ajar Tematik Dalam Pelaksanaan Kurikulum 2013. Jurnal Pedagogik. 05 (01): 100-108.

Al Qalam: Jurnal Ilmiah Keagamaan dan Kemasyarakatan

Vol. 14, No. 2, Januari-Juni 2020 
Tahap pengembangan diawali dengan kegiatan valaidasi oleh 3 orang ahli. Kegiatan validasi di lakukan dengan tujuan agar mendapatkan penilaian tentang kelayakan bahan ajar yang dikembangkan dan juga diharapkan mendapatkan saran dari 3 ahli tersebut agar bahan ajar handout mendapatkan perbaikan. Berikut hasil validasi dan saran dari beberapa ahli:

a. Validasi Ahli

Tabel 1 Hasil Validasi Ahli Bahan Ajar Handout

\begin{tabular}{|c|c|c|c|c|c|c|c|}
\hline \multirow{2}{*}{ Aspek } & \multirow{2}{*}{$\begin{array}{c}\text { Soal } \\
\text { Penilaian } \\
\text { Aspek } \\
\end{array}$} & \multicolumn{3}{|c|}{ Validator } & \multirow[b]{2}{*}{ Jumlah } & \multirow[b]{2}{*}{$\begin{array}{c}\text { Rata- } \\
\text { rata }\end{array}$} & \multirow[b]{2}{*}{$\begin{array}{c}\text { Total } \\
\text { Rata-rata }\end{array}$} \\
\hline & & (V1) & (V2) & (V3) & & & \\
\hline \multirow{3}{*}{ Kelayakan Isi } & 1 & 5 & 5 & 4 & 14 & 4,67 & \multirow{3}{*}{4.67} \\
\hline & 2 & 5 & 4 & 5 & 14 & 4,67 & \\
\hline & 3 & 4 & 5 & 4 & 13 & 4,33 & \\
\hline \multirow{3}{*}{ Kelayakan Bahasa } & 4 & 4 & 5 & 4 & 13 & 4,33 & \multirow{4}{*}{4.20} \\
\hline & 5 & 4 & 4 & 4 & 12 & 4,00 & \\
\hline & 6 & 4 & 4 & 4 & 12 & 4,00 & \\
\hline \multirow{4}{*}{ Penyajian } & 7 & 4 & 4 & 5 & 13 & 4,33 & \\
\hline & 8 & 4 & 4 & 4 & 12 & 4,00 & \multirow{3}{*}{4.11} \\
\hline & 9 & 4 & 4 & 4 & 12 & 4,00 & \\
\hline & 10 & 5 & 5 & 3 & 13 & 4,33 & \\
\hline \multirow{5}{*}{ Kelayakan Tampilan } & 11 & 4 & 5 & 5 & 14 & 4,67 & \multirow{5}{*}{4.40} \\
\hline & 12 & 4 & 5 & 4 & 13 & 4,33 & \\
\hline & 13 & 4 & 5 & 4 & 13 & 4,33 & \\
\hline & 14 & 4 & 5 & 5 & 14 & 4,67 & \\
\hline & 15 & 4 & 4 & 4 & 12 & 4,00 & \\
\hline \multicolumn{7}{|l|}{ Rata-rata Jumlah total } & 4.34 \\
\hline \multicolumn{7}{|l|}{ Kriteria } & $\begin{array}{l}\text { Sangat } \\
\text { Baik }\end{array}$ \\
\hline
\end{tabular}

Validasi ahli bahan ajar handout menunjukkan bahwa pada aspek kelayakan isi memperoleh rata-rata 4,67, aspek kelayakan bahasa rata-rata 4,20, aspek penyajian rata-rata 4,11 dan aspek kelayakan tampilan memperoleh rata-rata 4,40 sehingga skor total rata-rata 4,34 atau masuk dalam kriteria sangat baik. Bahan ajar handout sudah layak untuk diuji cobakan pada pembelajaran.

b. Kegiatan Ujicoba

Uji coba produk yang dilakukan secara terbatas. Tujuan uji coba terbatas yaitu mengetahui respon guru dan respon peserta didik terhadap penggunaan bahan ajar handout yang telah dikembangkan dalam proses pembelajaran. Subjek penelitian yang dilakukan pada saat ujicoba produk secara terbatas adalah peserta 
didik kelas IV SD Negeri Kembaran. Kegiatan ujicoba produk dibantu oleh guru kelas terhadap penggunaan bahan ajar handout kurikulum 2013 berbasis kompetensi abad 21 dengan menggunakan model pembelajaran kolaboratif tipe TPS (ThinkPair-Square).

4. Tahap Desiminate (Penyebaran)

Tahap disseminasi dilakukan untuk mempromosikan produk pengembangan agar bisa diterima pengguna, baik individu, suatu kelompok maupun sistem. Tahap diseminasi merupakan tahap publikasi hasil yang telah dikembangkan yaitu bahan ajar Handout kurikulum 2013 berbasis kompetensi peserta didik abad 21 Tema 7 Subtema 1 Pembelajaran 2 pada kelas IV SD Negeri Kembaran, UPK Kembaran, Kabupaten Banyumas. Diseminasi hasil pengembangan bahan ajar dilakukan melalui guru SD yang digunakan sebagai tempat penelitian. Bahan ajar Handout yang telah dikembangkan diserahkan pada pihak sekolah diwakili oleh kepala sekolah sebagai penerima bahan ajar Handout dan didampingi guru model kelas IV.

5. Respon guru pada bahan ajar Handout kurikulum 2013 berbasis kompetensi peserta didik abad 21 pada tema 7 subtema 1 pembelajaran 2 kelas IV SD Negeri Kembaran.

Tabel 2 Hasil Angket Respon Guru

\begin{tabular}{|c|c|c|c|}
\hline No & Aspek yang dinilai & Nilai & $\begin{array}{c}\text { Rata-rata } \\
\text { Skor }\end{array}$ \\
\hline \multicolumn{4}{|c|}{ Aspek Kedalaman Materi } \\
\hline 1. & Kejelasan tujuan pembelajaran. & 5 & \multirow[b]{2}{*}{4,5} \\
\hline 2. & $\begin{array}{l}\text { Kedalaman materi berbasis kompetensi peserta didik abad } 21 \text { (Critical } \\
\text { Thinking And Problem Solving, Communication, Collaboration, Creativity } \\
\text { And Innovation) dengan model kolaboratif tipe TPS (Think-Pair-Square). }\end{array}$ & 4 & \\
\hline \multicolumn{4}{|c|}{ Aspek Bahasa } \\
\hline 3. & Kalimat bahasa sesuai dengan kaidah EYD. & 5 & \multirow{2}{*}{5} \\
\hline 4. & Tingkat Kesukaran bahasa sesuai dengan pemahaman peserta didik. & 5 & \\
\hline \multicolumn{4}{|c|}{ Aspek Penulisan } \\
\hline 5. & Mengajak peserta didik aktif dalam pembelajaran & 4 & \multirow{2}{*}{4,5} \\
\hline 6. & Menumbuhkan motivasi dan kerjasama peserta didik. & 5 & \\
\hline \multicolumn{4}{|c|}{ Aspek Kegrafikan } \\
\hline 7. & Kemenarikan tampilan bahan ajar handout. & 5 & \multirow{4}{*}{5} \\
\hline 8. & Kesesuaian jenin font/huruf yang digunakan. & 5 & \\
\hline 9. & Terdapat kejelasan identitas. & 5 & \\
\hline 10. & Kejelasan gambar dan materi. & 5 & \\
\hline \multicolumn{2}{|c|}{ Jumlah Keseluruhan } & 48 & 19 \\
\hline \multicolumn{2}{|c|}{ Rata-rata } & \multicolumn{2}{|c|}{4,75} \\
\hline \multicolumn{2}{|c|}{ Kriteria } & \multicolumn{2}{|c|}{ Sangat baik } \\
\hline
\end{tabular}

Respon yang diberikan guru terhadap bahan ajar handout memperoleh skor rata-rata 4,75 yang berarti respon guru terhadap bahan ajar tersebut "sangat baik". Penilaian dilakukan oleh 
Wahyu Wulandari S.Pd sebagai guru kelas IV SD Negeri Kembaran, UPK Kembaran, Kabupaten Banyumas.

6. Respon peserta didik pada bahan ajar Handout kurikulum 2013 berbasis kompetensi peserta didik abad 21 pada tema 7 subtema 1 pembelajaran 2 kelas IV SD Negeri Kembaran.

Tabel 3 Hasil Angket Respon Peserta Didik

\begin{tabular}{|c|c|c|c|c|c|c|}
\hline \multirow{2}{*}{ No } & \multirow{2}{*}{ Pernyataan } & \multicolumn{5}{|c|}{$\begin{array}{c}\text { Pilihan Jawaban } \\
\text { Jumlah }\end{array}$} \\
\hline & & 1 & 2 & 3 & 4 & 5 \\
\hline \multicolumn{7}{|c|}{ Cakupan Isi Materi } \\
\hline 1. & Isi/Materi yang ada di bahan ajar handout mudah saya pahami. & 0 & 0 & 0 & 20 & 10 \\
\hline 2. & $\begin{array}{l}\text { Isi/Materi yang ada di bahan ajar handout menambah wawasan } \\
\text { dan pengetahuan saya. }\end{array}$ & 0 & 0 & 0 & 16 & 14 \\
\hline 3. & Bahan ajar handout bermanfaat sebagai sumber belajar bagi saya. & 0 & 0 & 2 & 13 & 15 \\
\hline 4. & $\begin{array}{l}\text { Materi yang diberikan membuat saya mampu berpikir kritis dan } \\
\text { memecahkan masalah, berkomunikasi, bekerjasama, berkreasi } \\
\text { dan inovasi. }\end{array}$ & 0 & 0 & 0 & 8 & 22 \\
\hline \multicolumn{7}{|c|}{ Cakupan Bahasa } \\
\hline 5. & $\begin{array}{l}\text { Bahasa yang digunkaan mudah saya pahami dan sederhana sesuai } \\
\text { dengan Kaidah Bahasa Indonesia (EYD) }\end{array}$ & 0 & 0 & 0 & 21 & 9 \\
\hline \multicolumn{7}{|c|}{ Cakupan Penyajian } \\
\hline 6. & $\begin{array}{l}\text { Tujuan dan Indikator pada bahan ajar handout yang ingin saya } \\
\text { capai jelas. }\end{array}$ & 0 & 0 & 0 & 20 & 10 \\
\hline 7. & $\begin{array}{l}\text { Saya senang dengan suasana pembelajaran menggunakan bahan } \\
\text { ajar handout tersebut. }\end{array}$ & 0 & 0 & 1 & 7 & 22 \\
\hline 8. & $\begin{array}{l}\text { Gambar ataupun ilustrasi lain mempermudah saya dalam } \\
\text { memahami materi. }\end{array}$ & 0 & 0 & 1 & 13 & 16 \\
\hline 9. & $\begin{array}{l}\text { Soal dan tugas yang diberikan membantu meningkatkan } \\
\text { pemahaman saya terhadap materi. }\end{array}$ & 0 & 0 & 2 & 10 & 18 \\
\hline \multicolumn{7}{|c|}{ Cakupan Tampilan } \\
\hline 10. & Sampul atau cover bahan ajar handout menarik. & 0 & 0 & 3 & 13 & 14 \\
\hline 11. & $\begin{array}{l}\text { Ukuran dan jenis huruf yang digunakan dalam bahan ajar handout } \\
\text { mudah saya baca. }\end{array}$ & 0 & 0 & 1 & 10 & 19 \\
\hline \multicolumn{2}{|r|}{ Jumlah Keseluruhan } & 0 & 0 & 10 & 151 & 169 \\
\hline \multicolumn{2}{|c|}{ Skor } & 0 & 0 & 33 & 592 & 865 \\
\hline \multicolumn{2}{|c|}{ Jumlah Skor } & \multicolumn{5}{|c|}{1490} \\
\hline \multicolumn{2}{|c|}{ Rata-rata } & \multicolumn{5}{|c|}{4,51} \\
\hline \multicolumn{2}{|c|}{ Kriteria } & \multicolumn{5}{|c|}{ Sangat Baik } \\
\hline
\end{tabular}

Pada tabel 3 menjelaskan bahwa masing-masing peserta didik yang berjumlah 30 diberikan lembar penilaian yang berisi 11 pernyataan. Respon dari peserta didik memperoleh rata-rata 4,51 maka dikategorikan "sangat baik". Dapat disimpulkan bahwa Handout dapat diterima oleh peserta didik sebagai bahan ajar menarik yang mampu membantu proses pembelajaran pada tema 7 subtema 1 pembelajaran 2 kelas IV. Sejalan dengan penelitian yang dilakukan oleh Ningtyas (2014) bahwa handout memperoleh respon yang positif dalam penggunaannya pada pembelajaran, 
penggunaan produk membuat peserta didik lebih menyenangkan dan menjadi lebih aktif. $^{15}$

\section{Kajian Produk Akhir}

Produk akhir yang dikembangkan berupa bahan ajar handout kurikulum 2013 berbasis kompetensi peserta didik abad 21 untuk peserta didik kelas IV SD Negeri Kembaran. Prduk akhir yang dihasilkan berdasarkan masukan, ssaran dan komentar yang diberikan oleh 2 dosen ahli dan 1 validator ahli guru/kepala sekolah untuk menilai kelayakan produk yang dikembangkan sehingga dapat memperbaiki sesuai dengan masukan, saran dan komentar sebelum diujicobakan. penelitian pengembangan ini adalah menghasilkan handout kurikulum 2013. Pengembangan handout menggunakan metode pengembangan melalui empat tahapan yaitu define, design, develop, dan disseminate sehingga dapat menghasilkan produk berupa handout yang baik dan berkualitas. Kompetensi yang harus dicapai dalam handout sesuai dengan kompetensi peserta didik abad 21. Sasaran utama pengguna handout yaitu peserta didik kelas IV SD Negeri Kembaran yang berjumlah 30 siswa. Alasan pemilihan sasaran tersebut dikarenakan handout yang digunakan oleh guru masih terbatas dan sederhana.

Judul handout yang digunakan yaitu Tema 7 Indahnya Keragaman di Negeriku. Materi I membahas tentang tanda tempo dan tangga nada. Materi 2 juga membahas mengenai pemanfaatn gaya otot. Sedangkan materi 3 membahas terkait menggali informasi teks. Setiap materi disesuaikan dengan aspek kompetensi peserta didik abad 21 yang terdiri dari berpikir kritis dan memecahkan masalah, komunikasi, kolaborasi, kreatifitas dan inovasi. Peserta didik diberikan tugas pada setiap materi yang telah diberikan.

\section{Simpulan}

Berdasarkan proses penelitian dan hasil pengembangan bahan ajar kelas IV tema Indahnya Keragaman dinegeriku Subtema 1 Pembelajaran ke 2 dapat disimpulkan bahwa bahan ajar handout kurikulum 2013 berbasis kompetensi peserta didik abad 21 pada tema 7 subtema 1 pembelajaran 2 layak digunakan sebagai solusi pembaruan bahan ajar yang menarik dan menyenangkan karena mempunyai kriteria valid, praktis dan efektif sehingga dapat membantu proses pembelajaran

${ }^{15}$ Ningtyas, R \& Yunianta, T, N, H. 2014. Pengembangan handout pembelajaran tematik untuk siswa sekolah dasar kelas III. Scholaria. 4 (3): 42-53. 


\section{Saran}

Saran untuk peneliti selanjutnya yaitu

1. Analisis kebutuhan sebaiknya dilakukan secara mendalam tidak hanya berdasarkan wawancara dengan guru tetapi juga mengumpulkan data dan informasi dari pihak terkait lainnya agar produk yang dikembangkan menjadi lebih berkualitas.

2. Produk handout ini hanya membahas satu pembelajaran. Peneliti selanjutnya diharapkan mampu mengembangkan bahan ajar handout lebih dari satu pembelajaran.

3. Uji coba lapangan bisa dilakukan dengan responden yang lebih banyak lagi karena semakin banyak revisi dari responden maka handout akan memiliki kualitas yang lebih baik.

\section{DAFTAR PUSTAKA}

Anriani, N., \& Fathurrohman, M. 2018. Pengembangan bahan ajar matematika berbasis kompetensi abad 21 untuk guru smp / mts. Prosiding Seminar dan Diskusi Nasional Pendidikan Dasar 2018. 1-5, diakses 05 November 2019.

Boonjeam, dkk. 2017. Program development for primary school teachers 'critical $\begin{array}{lllll}\text { thinking'. International Education } & \text { Studies. } 10 & \text { (02). }\end{array}$ https://files.eric.ed.gov/fulltext/EJ1130350.pdf, diakses pada 22 Januari 2020

Fajri, Z. 2018. Bahan Ajar Tematik Dalam Pelaksanaan Kurikulum 2013. Jurnal Pedagogik. 05 (01): $100-108$.

Hodiyanto. 2017. Kemampuan komunikasi matematis dalam pembelajaran matematika. Admathedu. 7 (01): 9-18.

Kemendikbud. 2013. Peraturan Menteri Pendidikan dan Kebudayaan No 67 Tahun 2013, tentang Kerangka Dasar dan Struktur Kurikulum SD/MI. Jakarta: Kementerian Pendidikan dan Kebudayaan Direktorat Jenderal Pendidikan Dasar.

Kurniaman, O., \& Noviana, E. 2017. Penerapan Kurikulum 2013 Dalam Meningkatkan Keterampilan, Sikap, Dan Pengetahuan. Primary: Jurnal Pendidikan Guru Sekolah Dasar. 6 (2): 389-396.

Ningtyas, R \& Yunianta, T, N, H. 2014. Pengembangan handout pembelajaran tematik untuk siswa sekolah dasar kelas III. Scholaria. 4 (3): 42-53.

Octaviani, S. 2017. Pengembangan Bahan Ajar Tematik Dalam Implementasi Kurikulum 2013 Kelas 1 Sekolah Dasar. EduHumaniora Jurnal Pendidikan Dasar Kampus Cibiru. 9 (2): 93-98.

Prastowo, A. 2014. Pengembangan Bahan Ajar Tematik. Jakarta: Kencana Prenada Media Group.

Prastowo, A. 2015. Panduan Kreatif Membuat Bahan Ajar Inovatif. Jogjakarta: DIVA Press.

Susanti, D., \& Risnanosanti. 2019. Pengembangan Buku Ajar untuk Menumbuh kembangkan Kemampuan 4C (Critical, Creative, Collaborative, 
Dhini Aprilia Utami, Sony Irianto, Sri Muryaningsih : Pengembangan Handout Kurikulum 2013 Berbasis Kompetensi Peserta Didik Abad 21 Kelas IV Di SD Negeri Kembaran

Communicative) melalui Model PBL pada Pembelajaran Biologi di SMP 5 Seluma. Prosiding Seminar Nasional Sains Dan Enterpreneurship VI. 1-9, diakses 11 Januari 2020.

Susanto, W. N., \& Nurtjahyani, S. D. (2018). Pengembangan Handout Biologi Berbasis Discovery Learning pada Materi Interaksi Mahluk Hidup dengan Lingkungannya Development of Discovery Learning Based Biology Handout on Creative Interaction Materials With its Environment. Proceeding Biology Education Conference, 15, 471-477.

Trianto. 2013. Mendesain Model Pembelajaran Inovatif-Progresif. Jakarta: Kencana Prenada Media Group.

Wijaya, E. Y., Sudjimat, D. A., \& Nyoto, A. (2016). Transformasi Pendidikan Abad 21 Sebagai Tuntutan Pengembangan Sumber Daya Manusia Di Era Global. Jurnal Pendidikan, 1, 263-278.

Yaqin, M., A, dkk. 2018. Think-pair-square learning: improving student's collaborative skills and cognitive learning outcome on animal diversity course. Jurnal Pendidikan Biologi Indonesia (Indonesian Journal of Biology Education). 4 (2):135-142. 